\title{
School Facilities Are Grooming Primary Schools Academic Performance in Pakistan: A Longitudinal Evidence from Punjab Province
}

\author{
Sabika Khalid ${ }^{1}$, Endale Tadesse ${ }^{1} \&$ Chunhai Gao $^{2}$ \\ ${ }^{1}$ Faculty of Education, Southwest University, China \\ ${ }^{2}$ Research Center of Brain and Cognitive Neuroscience, Liaoning Normal University, Dalian, China \\ Correspondence: Endale Tadesse, Faculty of Education, Southwest University, Chongqing, China. Tel: \\ 86-186-2318-3912. E-mail: endaletadesse2017@gmail.com
}

Received: November 24, 2020

Accepted: December 15, 2020

Online Published: December 30, 2020

doi:10.5539/ass.v17n1p42

URL: https://doi.org/10.5539/ass.v17n1p42

\begin{abstract}
The Pakistan government is exhausted with the despicable rate of return from education. Punjab province took the preponderance amount of the budget for quality education due to the large population density. Thus, this study longitudinal study embraces the distribution and effectiveness of necessary facilities that consume most educational budgets through extensive analysis. Hence, the main finding indicated that the Punjab province showed a radical improvement in resource equity and student learning outcomes. However, the study noted that a lot has to be done to evaluate resources since significant improvements are observed, but not an achievement.
\end{abstract}

Keywords: primary education, sanitation, facilities, MANOVA, Punjab

\section{Introduction}

Countries call for providing adequate and attribute school facilities to keep the school climate's harmony that induces an effective teaching and learning environment. School facilities comprise school buildings, drinking water, electricity, and usable toilet that are the foundation and coherent to run a school fluently (Maphoso and Mahlo, 2014; Jasper et al., 2012). School is the second house of children since they spend a considerable time of their day in the school (Durán-Narucki, 2008). Chan's consecutive study claimed that physical facilities significantly positively or negatively influence one brain's psychological reaction (Chan \& Petrie, 1998).

Moreover, scholars noted that a limited number of studies have evolved to strengthen the evidence of the relationship between school facilities and student academic achievement (Durán-Narucki, 2008). In an education setting, learner and school staff health and safety can be assured by sufficient school facilities that requisite for admirable learning outcome (Uline \& Moran, 2008) and the learning outcome of students mostly measured by test or examination score which confirmed its relation to the country's' economic growth and development (Hanushek \& Woßmann, 2010; Aslam, 2003). Educational policy-makers retain standard examination as the primary means of measuring inputs' effectiveness (Aslam, 2003). The fact that school facilities' availability is not the only predictor of educational effectiveness and the age of the existing school facilities is a significant predictor of the vigorous educational process enhancing student achievement (Earthman, 2004; Durán-Narucki, 2008). Earlier 232 references review by Earthman and his colleague indicated that students with standard school facilities perform higher in examination than their counterparts with inadequate facilities (Earthman \& Lemasters, 1996). However, their finding criticized inconsistent results (Picus et al., 2009). On the other hand, low-quality and inadequate school facilities' availability hurdles or jeopardizes students' learning outcomes and negatively influences determinants of student achievement and education equity (Chan, 1996; OECD, 2019).

The odds effective learning environment has disrupted that influence students' inadequate learning outcome (Uline \& Moran, 2008). According to the analysis result, Chudga and colleagues accept their hypothesis that family factors and student characteristics are the essential predictors of student academic achievement, negating water, toilet, and electricity (Chudga et al., 2015). In the same vein, a longitudinal study in the USA indicated that the condition of school facilities and student examination scores has no relationship (Picus et al., 2009). However, Chunga and colleagues acknowledge the unbearable powerful influence of primary school facilities, especially for low-income or poverty-stricken countries. Hence, due to the sensitiveness of primary facilities for 
developing countries, socioeconomic status (SES) and child characteristics are insignificant (Murillo and Roman, 2011). As a result of fast economic development, availability of primary facilities, and its relation to learning outcome became out of the equation; a recent study in swiftly developing South Africa argued that school with adequate school facilities outmatch their equivalents from low primary facility schools (Maphoso and Mahlo, 2014). Most of the rest were plagued with methodological problems and, not surprisingly, produce conflicting, ambiguous results (Picus et al., 2009). Unfortunately, poverty-stricken countries are still struggling with fulfilling the fundamental needs of primary schools.

Moreover, primary school is a crucial education level that predicts students' psychological motives, and performance towards education is highly dependent on the nature of physical facilities that they sense and impact on their next level of education performance (Durán-Narucki, 2008). In this regard, the school needs to have a standard facility which is not aged or outdated; the age of the school building is the primary factor to assess the status of the school facility (Chan, 1996; Earthman \& Lemasters, 1996; O'Neill \& Oates, 2001; Aslam et al., 2019). A Texas study at middle school demonstrates that the school building's age strongly correlates with student grade eight examination results than any other factor (O'Neill \& Oates, 2001). Studies also investigated school facility distribution across rural and urban, Nigerian study noted that qualified teachers migrate to urban schools while rural schools became school without teachers (Sunday \& Olatunde, 2011). Nevertheless, their finding indicated that rural students are outperforming their urban school counterparts with more advanced facilities. This observation's rationale is urban student exposure to excessive technology and entertainment (Sunday \& Olatunde, 2011). The explanation for this finding might be a common feature of small-sized schools, and students at rural schools and small-size schools perform better since they are easy to manage student and staff (Chudga, 2015; Rahim, 2017; OECD, 2019).

Besides, studies argued that students' health and wellness have been compromised in poverty-stricken countries due to inadequate facilities that led to low student performance (Durán-Narucki, 2008; Jasper et al., 2012). Global report also highlighted that rural schools lack electricity due to funders' preference for school donations (UNDESA, 2014; OECD, 2019). PISA 2015 result sheds light that urban schools outperform rural by a 31-point score; on the other hand, "minority" (developed countries), which is minimizing the Urban-Rural school facility distribution gap, is exhibiting tremendous economic development (OECD, 2019).

A recent, most "minority" countries' education does not have a school facility's influence on achievement due to zero resource disparity between schools (Murillo \& Roman, 2011). The study noted that the health and well-being of the necessary facilities at primary school are essential (Jasper et al., 2012; UNICEF, 2018). Despite the studies highlighting the school's primary facilities, electricity is necessary for transparent teaching and learning activities in the classroom to conduct teaching with a different multimedia device (Maphoso \& Mahlo, 2014; UNDESA, 2014). On the contrary, another report noted that in most developing countries, schools operate during the daytime due to the lack of electronic devices, making electricity minor (OECD, 2019). Likewise, by dint of the paramount significance of electricity conducting the productive teaching-learning process, primary students' achievement is on the hand of electricity availability (Murillo \& Roman, 2011; Maphoso \& Mahlo, 2014). The results in more than 188 a million primary school children in the world to access a school without electricity, and Pakistan and Nigeria are the leading countries (UNDESA, 2014).

Further, a Latin American study confirmed that primary school students showed academic achievement of drinking water availability (Murillo \& Roman, 2011). However, the degree of impact by drinking water availability in the school on student academic achievement varies from country to country. (Murillo \& Roman, 2011) seem to indicate a weak relationship, while studies carried out in disadvantaged society noted a robust relationship (Glewwe, 2002). A preceding review study conducted in developing countries stated that from 34 reviewed studies, 22 studies found a statistically significant positive link between school facilities and student academic performance, 3 established negative influence, and the remaining 9 pointed no significant relation (Hanushek, 1997). Likewise, according to the UNICEF report cited in (Maphoso \& Mahlo, 2014) mentioned, student absentees and low academic performance resulted from drinking water. In the $21^{\text {st }}$ century, it is ridiculous discussing toilets; however, schools in most developing countries are still facing inadequacy of sanitation infrastructure. Pakistan's neighboring country India has identical educational challenges. Still, India stepped up in 2003 by launching a national campaign that prioritized sanitation building before school, boosts primary school enrollment but not academic progress (Adukia, 2016). Correspondingly, a study in Ghana confirmed a significant relationship between school infrastructure and student achievement, but the study stressed that necessary facilities had an insignificant influence on student learning outcomes (Glewwe \& Jacoby, 1994).

Fortunately, a systematic review on 47 studies around the world discloses the decisive of necessary facilities in keeping the wellness and psychological stability of students in showing intended learning outcome and the 
review urge future systematic methodological studies to achieve universal access to education as a right for all children through evidence-based this studies (Jasper et al., 2012). In the same vein, a previous study noted school facilities repute in enhancing educational and non-educational outcomes. Still, they claimed that researchers challenge statistically demonstrating school facilities' influence on student learning outcomes (Picus et al., 2009). Ultimately, fewer available studies show that research shows can improve student learning (Picus et al., 2009). We can remark that more have to be explored to underline the influence of necessary facilities on student learning. For that reason, scholars have to look at the research setting phenomena deep in a more systematically statistical method to understand and forward a valid implication.

\subsection{Research Context}

The aim and goal of Pakistan's educational policy are to meet the national visions and international goals set to promote education quality. The panorama has posed a double challenge for the government of Pakistan: on one hand country has a large number of out of school children (OOCS), which is 22.84 million, and on the other, according to Article 25-A the education is compulsory from age 5-16; to obtain the set target the government set goals, to reduce barriers that generate this vulnerable situation, learn access risks, enrollment, participation, school facilities, are the barriers to eliminate to achieve the student participation and achievement (Nisar et al., 2017; Government of Punjab, 2020). Pakistan spends hardly 2\% of the gross national product on education as a much lower percentage than comparable countries. Also, Pakistan criticized its inefficient use of the expenditure; due to the consecutive low education rate of return. Primary education achievement in Pakistan is declining from time to time due to the unavailability of school resources in charge of the quality teaching-learning process (Hamza, 2016; Hussain, 2018). These have motivated us to approach less known educational phenomena to obtain a broad overview of the necessary facilities relationship with student achievement across urban and rural at the province level (Tayyaba, 2012). For that reason, Punjab province is working with the national educational bureau and international funders to keep the school infrastructure uniform among all schools due to Punjab education's unintended return (Aslam et al., 2019: Government of Punjab, 2020). The Punjab government launched the 2023/24 education plan, which increases access to necessary facilities to promote quality of education as a preliminary plan to meet the global SDG 4 objectives (Government of Punjab, 2020).

To know how primary schools in Punjab face this double challenge, the school resources, and student achievement, we examine the district level examination results to identify students' outcomes and what availability of resources at the district level in Punjab. "Developed, industrialized, just and prosperous Pakistan through rapid and sustainable development in a resource-constrained economy by developing knowledge inputs" (Pakistan vision 2030). Studies in "minorities" (developed) countries referred that the availability and nature of necessary facilities relationship with student academic achievement fall out (Picus et al., 2009; Murillo \& Roman, 2011; OECD, 2019). As those minority countries, Pakistan's primary school pupil academic achievement is also directly determined by family, school, and personal factors (Tayyaba, 2012; Nisar et al., 2017). However, for less developing countries like Pakistan, school infrastructures are more prominent than out-school factors on student academic achievement (Aslam, 2003; Tayyaba, 2012; Hamza, 2016). A national-level study in Pakistan by Tayyaba stated no significant effect of family size, distance from school, and socioeconomic status on student learning outcomes. These factors do not exhibit any variance between the country's rural and urban parts (Tayyaba, 2012).

On the contrary, Nisar and colleagues' survey study argued that socioeconomic status and student characteristics are the most predictors of academic achievement. Still, the study remarkably lacks evidence analysis to conclude with only 60 students sample surveys (Nisar et al., 2017). Fortunately, a recent study in Punjab and KP province with rich data indicated that primary education achievement has nothing to do with students' socioeconomic status (Rahim, 2017; Aslam, 2019). Rahim's study used large-scale data indicating that school facilities groomed language test scores in Pakistan (Rahim, 2017). Even though English is a medium of primary education instruction since 2013, Punjab's primary student academic progress in English national scores is declining throughout the year, and rural schools scored a lot less (Government of Punjab, 2020). As a consequence of foreign language as a primary medium of instruction at primary education in a country like Pakistan with a high illiterate and rural population, teaching-learning gets stiff, so Punjab has decided to use it (Urdu) primary education medium of instruction.

The shift towards a more comprehensive school that certifies equity and equality for all is the multifaceted challenge for 21 st-century education that guarantees academic success, value, and prosperity. School development plan and improvement in students' outcomes took seven years in Punjab, and the government meets 43,000 missing facilities in school and 7400 building reconstruction and repair. Hence, the feeble association between spending and educational performance is also indicated by PISA results. Schools with all available 
resources must utilize these resources for significant outcomes (OECD, 2010a). Unluckily the school facilities are insufficient in Pakistan.

Apart from the availability of these school facilities, the optimal usage of these facilities is also essential. Only the distribution decision of resources across the education system is not enough; the proper monitoring and ensuring of these facilities are necessary to improve this gap. The efficient and appropriate use of school resources affects the students' academic performance, and their inefficient use impacts student academic loss (Hanushek, 1997). According to a recent study, in Indian primary schools, female students are attacked or raped for urinating behind school due to the absence of a toilet (Adukia, 2016). That is the paramount significance of the study by essential facility influence beyond students' academic achievement and well-being and health (Durán-Narucki, 2008; Jasper et al., 2012; Hamza, 2016: UNICEF, 2018)).

Moreover, Adukia's study indicated no relationship between sanitation and pupil academic scores, but the study was limited to an insignificant number of systematic analysis data (Adukia, 2016, p. 25). Pakistan is currently the second rank in less water availability in Asia, next to Nepal (UNICEF, 2018). The UNICEF report stated that students' cognitive skills, memory, and interest in education are enhanced by drinking water intervention.

The study sets in Punjab Province, where is the most populated and dense of the six provinces. Based on the 2018/19 Punjab bureau of statistics report statistics, Punjab comprises 36321 primary schools and more than 4.8 million primary age children enrolled. From the total population of 110 million (almost half of the total population of Pakistan), 63\% of it settle in the rural part of the province, and they are notably disadvantaged compare to urban society in terms of access to quality education (Tayyaba, 2012; Government of Punjab, 2020). However, a survey on the national level in Pakistan indicated that rural school with adequate necessary facilities demonstrate outstanding achievement than their urban peers and particularly in Punjab province the study noted that no science and math score across a location of schools that contradict with the traditional conjecture of rural school stereotype regarding Science and Math subject performance on standardized exams (Tayyaba, 2012).

The province educational office conducts a national exam for primary, middle, and secondary schools every year to evaluate the educational expenditure and resources, spend on education met the goal and scholars mentioned that achievement score is the rigorous way of assessing (Aslam, 2003; Hamza, 2016; Hussain, 2018; Government of Punjab, 2020). Because enhancing student academic achievement is a crucial concern for policy-makers in developing countries through significant investment in educational resources (Glewwe \& Jacoby, 1994). According to the 1999 national primary school examination result of Punjab, it was found that the overall subject means the result of Punjab province was $25.1 \%$, which is relatively low (Hussain, 2018). A recent report by the Punjab government also sheds light on primary student national examination scores low performance on critical subjects that assess elementary numeracy and literacy skill to date (Government of Punjab, 2020).

As a result of Pakistan is driving a gigantic enrollment, the size of primary schools is getting more expansive, and that less attention by teachers and school leaders towards student academic progress and less access to necessary facilities and Punjab is a prime model for experiencing this phenomenon (Rahim, 2017). A recent study confirmed that most provinces in Pakistan, including this study, target province Punjab, have a large school size (Tayyaba, 2012).

\section{Research Method}

This longitudinal study is in Punjab province, where more than half of the Pakistani population lives, and rigorous large-scale data available were available (Government of Punjab, 2020). The government has invested in school infrastructure to provide necessary facilities like clean drinking water, toilets, sewerage system, and electricity to run schools smoothly. For that reason, the study used (2016, 2017, and 2018) primary school census of Punjab to examine the direct influence of primary school facilities (drinking water, electricity, sewerage, and toilet) on school achievement, whereas school location and building condition acted as confounding variables which predict school performance. Subsequently, we used the data set provided by the Punjab government's educational office, and after cleansing, we consider all available public primary schools with complete information. That implies that the study employed a large primary school scale to obtain more reliable and concrete findings that the study intended to contribute to effective interventions for the policy practice and rigorous contribution to theory.

\subsection{Data Analysis and Result}

Two-way ANOVA and multivariate analysis of variance (MANOVA) analysis were employed to achieve the study's purpose. The data were analyzed using Multivariate Analysis of variance (MANOVA), which enabled us 
to remove the extraneous variables that affect the predictor variable measured independently on the criterion variables (see Figure 1). Put simply, the primary purpose of the MANOVA is to understand if there is an effect of two or more independent variables on the two or more dependent variables. Since our study contains multiple dependent variables, two-way MANOVA analysis enabled us to investigate the effect of primary school essential facility availability, school location, and building condition on Punjab primary education national examination score. (See. Figure 1 below)

Table 1 below exhibits each categorical variable's nature and trait, which is regressed into the analysis. Thus, the preliminary information we need to stress here is the increment of primary school across the year; since we discard several schools from the data census due to incomplete information content, the table could not show the province progress in access to education, especially in the rural part of the province. The province education has shown a radical improvement of facilitating primary schools with sanitation that was frequent criticism the country was experiencing. Still, Punjab's primary school looks that they are changing the bad name given to the country. The table indicates that more than $95 \%$ of schools acquired sanitation facilities throughout the year, but there are still schools with a significant treatment of unsafe school building, environment, and facilities.

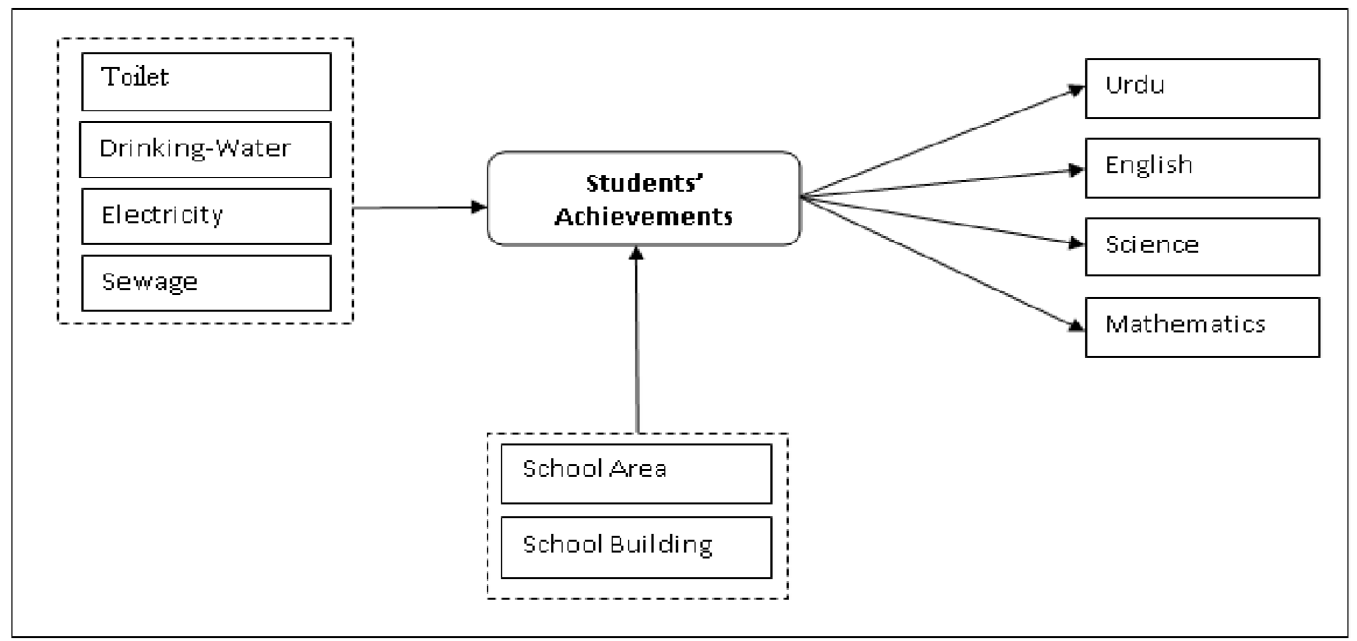

Figure 1. Conceptual framework showing the variables affecting school performance

Table 1. Nature of Categorical variables

\begin{tabular}{|c|c|c|c|c|c|}
\hline \multirow{2}{*}{ Categorical Variables } & & \multirow{2}{*}{ Coding } & \multicolumn{3}{|c|}{ Frequency } \\
\hline & & & 2016 & 2017 & 2018 \\
\hline \multirow{2}{*}{ Location of school } & Rural & 1 & 30044 & 31974 & 30044 \\
\hline & Urban & 2 & 3087 & 2899 & 3087 \\
\hline \multirow{5}{*}{ Building Condition } & The whole building in danger & 1 & 446 & 359 & 446 \\
\hline & The whole building repairable & 2 & 1053 & 852 & 1053 \\
\hline & Minor Danger & 3 & 961 & 823 & 961 \\
\hline & Minor Repair & 4 & 5640 & 9388 & 5640 \\
\hline & Satisfying & 5 & 25031 & 23451 & 25031 \\
\hline \multirow{2}{*}{ Drinking water } & Absent & 0 & 163 & 161 & 163 \\
\hline & Present & 1 & 32968 & 34712 & 32968 \\
\hline \multirow{2}{*}{ Electricity } & Absent & 0 & 858 & 1253 & 858 \\
\hline & Present & 1 & 32267 & 33620 & 32267 \\
\hline \multirow{2}{*}{ Sewerage } & Absent & 0 & 3182 & 3331 & 4384 \\
\hline & Present & 1 & 19879 & 31542 & 28746 \\
\hline \multirow{2}{*}{ Toilet } & Absent & 0 & 4384 & 166 & 49 \\
\hline & Present & 1 & 28746 & 34707 & 33072 \\
\hline
\end{tabular}

Table 2 shows the mean result of the subject result of primary school national examination across consecutive three years, and the result shows that the average result across demonstrated significant progress. Likewise, the progression did not only reflect only the overall result but also subject wise; For instance, English, math, and 
Science examination scores exhibit a tremendous score advancement. However, if we see deeply, the result demonstrates that significant progress was observed in the year 2017. Urdu, English, Science, and Math had a significant difference of 2.72, 4.48, 5.58, and 6.68 respectively after 2016, and on the other hand, 2018 did not show a promising improvement as of 2017 has to be noted.

Table 2. A descriptive explanation of Examination score in the timeline

\begin{tabular}{ccccccc}
\hline \multirow{2}{*}{ Subjects } & \multicolumn{2}{c}{$2016(\mathrm{~N}=31545)$} & \multicolumn{2}{c}{$2017(\mathrm{~N}=34873)$} & \multicolumn{2}{c}{$2018(\mathrm{~N}=33131)$} \\
\cline { 2 - 7 } & Mean & SD & Mean & SD & Mean & SD \\
\hline Urdu & 59.1561 & 3.89 & 61.88 & 3.14 & 62.72 & 3.40 \\
English & 50.9683 & 4.15 & 55.45 & 3.99 & 59.27 & 4.64 \\
Science & 49.4492 & 4.77 & 55.03 & 3.96 & 56.63 & 4.05 \\
Math & 54.4546 & 4.58 & 61.14 & 3.39 & 61.22 & 4.25 \\
Overall Result & 56.3216 & 3.61 & 60.72 & 3.03 & 61.48 & 3.45 \\
\hline
\end{tabular}

Table 3 shows below the result of examination results across the school location (Rural vs. Urban), which took several scholars' concerns due to its sensitiveness. The two-way ANOVA result demonstrates that rural primary school exceeds their urban counterparts in the mean result of national examination across each year which is brand new phenomena in the educational setting. Likewise, the result indicates that there is a significant examination score difference among rural and urban schools except for English subject, the result shown above demonstrate that 2016 was a year in which rural school had the highest significant statistical overall subject result than that of urban schools $(\mathrm{F}(1,31545)=21.300, \mathrm{P}=0.000)$ which is explained by the $\eta^{2}=.357$ or $35.7 \%$ of the variance. From all subjects, rural schools outperform urban schools in Science subject which requires sophisticated instructional materials which are considered not to be found at rural schools with statistical significance of a value $\eta^{2}=.537$, or $53.7 \%$ of the variation of science score was predicted by the school location difference $(\mathrm{F}(1,31545)=17.933, \mathrm{P}=0.000)$. However, English subject result in each year did not show any significant difference among rural and urban primary school in Punjab, means school location has so significant effect on primary school English test score from 2016-2018; $(\mathrm{F}(1,31545)=3.330, \mathrm{P}>.06),(\mathrm{F}(1,34873)=$ $1.567, \mathrm{P}>.20)$, and $(\mathrm{F}(1,33131)=3.945 ., \mathrm{P}>.04)$ respectively. Although all subject scores have a significant difference among rural and urban areas, most public schools are from the province's rural region regardless of the English subject. (See Table 1).

Table 3. The distribution of examination score between rural and urban school

\begin{tabular}{|c|c|c|c|c|c|c|c|}
\hline \multirow[b]{2}{*}{ Dependent Variables } & \multirow[b]{2}{*}{ Years } & \multicolumn{6}{|c|}{ School Location } \\
\hline & & Rural & Urban & $\mathrm{df}$ & $\mathrm{F}$ & $\mathrm{P}$ & $\eta^{2}$ \\
\hline \multirow{3}{*}{ Mean Score } & 2016 & 56.309 & 55.463 & 1 & 21.300 & .000 & .357 \\
\hline & 2017 & 60.634 & 60.030 & 1 & 10.087 & .001 & .552 \\
\hline & 2018 & 61.337 & 60.875 & 1 & 7.601 & .006 & .479 \\
\hline \multirow{3}{*}{ Science } & 2016 & 49.455 & 48.429 & 1 & 17.933 & .000 & .423 \\
\hline & 2017 & 54.892 & 53.935 & 1 & 14.781 & .000 & .537 \\
\hline & 2018 & 56.638 & 56.032 & 1 & 9.506 & .002 & .462 \\
\hline \multirow{3}{*}{ Math } & 2016 & 54.430 & 53.323 & 1 & 22.761 & .000 & .472 \\
\hline & 2017 & 60.994 & 60.351 & 1 & 9.054 & .003 & 521 \\
\hline & 2018 & 61.058 & 60.473 & 1 & 8.036 & .005 & .502 \\
\hline \multirow{3}{*}{ Urdu } & 2016 & 59.115 & 58.405 & 1 & 12.888 & .000 & .512 \\
\hline & 2017 & 61.693 & 61.296 & 1 & 4.006 & .045 & 529 \\
\hline & 2018 & 62.403 & 62.140 & 1 & 2.536 & .111 & .510 \\
\hline \multirow{3}{*}{ English } & 2016 & 50.953 & 50.569 & 1 & 3.330 & .068 & .163 \\
\hline & 2017 & 55.433 & 55.118 & 1 & 1.567 & .211 & .472 \\
\hline & 2018 & 59.010 & 58.562 & 1 & 3.945 & .047 & .513 \\
\hline
\end{tabular}

Significant Univariate Effects for School location (at p<.001 level)

Note: effect size $=\eta 2$ or partial $\eta 2 .{ }^{*} \mathrm{p}<.05 . \dagger \mathrm{p}<.01 . \pm \mathrm{p}<.001$

The following analysis method employed in the study was MANOVA, which is explained in Table 4 to investigate the school building condition's effect on Punjab primary schools' examination scores. Hence, the result implies that in 2016 and 2017, the average primary school examination result presents a statistically 
significant disparity between schools with distinct classroom conditions. Building condition predicts $39.2 \%$ and $41.5 \%$ variation of mean score result of school performance. In these two years, schools with pleasant level of classroom condition scored higher overall score than schools with unwelcome learning environment $(\mathrm{F}(1,31545)$ $=2.946 ., \mathrm{P}<0.05)$ and $(\mathrm{F}(4,34873)=3.884 ., \mathrm{P}<0.01)$ respectively. On the other hand, the 2018 overall result states that there is no significant mean score difference among school classroom conditions $(\mathrm{F}(4,33131)=$ 1.731., $\mathrm{P}>0.14$ ); the explanation for this finding might be due to reduction and renovation of unsafe school buildings. (See Table 1). Likewise, MANOVA subject wise result noted that 2017 all subject score shows a high statistical significant difference across classroom building circumstance (Science F $(4,34873)=7.939$., $\mathrm{P}<$ 0.001), $($ Math F $(4,34873)=7.939 ., P<0.001)$ and $(\operatorname{Urdu} F(4,34873)=5.191 ., P<0.001)$. On the contrary, the MANOVA illustrates that the English subject score was not affected by the classroom setting's condition, which is an identical result noted in the previous ANOVA analysis. (See Table 3)

Table 4. The effect of school building condition on school performance

\begin{tabular}{ccccccccccc}
\hline & & & & \multicolumn{7}{c}{ Building Condition } \\
\hline DV & & $\mathrm{df}$ & $\mathrm{F}$ & $\mathrm{P}$ & $\eta^{2}$ & 1 & 2 & 3 & 4 & 5 \\
\hline \multirow{3}{*}{ Mean Score } & 2016 & 1 & 2.946 & .019 & .392 & 56.196 & 55.491 & 55.714 & 56.105 & 59.926 \\
& 2017 & 4 & 3.884 & .001 & .415 & 58.878 & 59.914 & 60.070 & 60.331 & 60.967 \\
& 2018 & 4 & 1.731 & .140 & .514 & 61.232 & 60.762 & 61.224 & 61.093 & 61.218 \\
Science & 2016 & 1 & 3.330 & .010 & .387 & 49.173 & 48.476 & 48.692 & 49.308 & 49.060 \\
& 2017 & 4 & 7.939 & .000 & .421 & 55.253 & 53.755 & 54.004 & 54.360 & 54.693 \\
& 2018 & 4 & 1.156 & .328 & .531 & 56.746 & 55.983 & 56.491 & 56.206 & 56.249 \\
Math & 2016 & 1 & 1.969 & .096 & .382 & 54.497 & 53.342 & 53.685 & 53.989 & 53.869 \\
& 2017 & 4 & 2.901 & .003 & .424 & 60.990 & 60.200 & 60.587 & 60.737 & 60.848 \\
& 2018 & 4 & 1.298 & .268 & .531 & 60.938 & 60.434 & 60.843 & 60.729 & 60.884 \\
Urdu & 2016 & 1 & 2.682 & .030 & .395 & 58.984 & 58.509 & 58.517 & 59.002 & 58.789 \\
& 2017 & 4 & 5.191 & .000 & .428 & 61.875 & 60.998 & 61.337 & 61.539 & 61.723 \\
& 2018 & 4 & 5.870 & .070 & .522 & 62.085 & 61.920 & 62.399 & 62.343 & 62.611 \\
\multirow{2}{*}{ English } & 2016 & 1 & 2.527 & .039 & .398 & 51.260 & 50.221 & 50.809 & 50.857 & 50.657 \\
& 2017 & 4 & .825 & .211 & .432 & 55.766 & 55.009 & 55.016 & 55.319 & 55.268 \\
& 2018 & 4 & 2.202 & .066 & .536 & 58.598 & 58.462 & 58.792 & 58.977 & 59.102 \\
\hline
\end{tabular}

Note: effect size $=\eta 2$ or partial $\eta 2$.

Further, Table 5 exercised a Multivariate analysis of variance (MANOVA) due to multiple dependent variables the study encountered. The result indicates that in the 2018 examination score across the province, no significant mean and subject score difference was observed, including among schools with distinct availability of Sanitation infrastructure or basic school facilities. In other terms, sanitation and basic facilities' accessibility has no significant effect on school national examination performance. Further, the fundamental rationale or justification for the finding is the smooth approachability of sanitation or basic school facilities in recent years (See Table 1). Likewise, in the last few years, as a result of legal accessibility of electricity in the schools across the rural and urban year by year, the result shows that there is no subject score variation between schools or the presence of electricity cannot predict school achievement anymore (English result for instance from 2016-2018; (F (1, 31545) $=4.611, \mathrm{P}<.05),(\mathrm{F}(1,34873)=1.749, \mathrm{P}>.18)$, and $(\mathrm{F}(1,33131)=.389 ., \mathrm{P}>.53)$. Similarly, the availability of toilet in the school and its effect on student learning outcome was the center of several studies' attention. The MANOVA result illuminates that by dint of the Punjab government and non-governmental organization intervention in facilitating sanitation in public schools, the toilet has lost its effect on student academic achievement throughout the year $(\mathrm{F}(1,31545)=4.778, \mathrm{P}<.05),(\mathrm{F}(1,34873)=.200, \mathrm{P}>.65)$, and $(\mathrm{F}(1,33131)$ $=.124$., $\mathrm{P}>$.72).

Table 5. The effect of sanitation and basic facilities on school performance

\begin{tabular}{|c|c|c|c|c|c|c|c|c|c|c|c|c|c|}
\hline \multirow[b]{3}{*}{ DV } & & \multicolumn{12}{|c|}{ Basic Facilities 1} \\
\hline & & \multicolumn{6}{|c|}{ Drinking water } & \multicolumn{6}{|c|}{ Electricity } \\
\hline & & $\mathrm{df}$ & $\mathrm{F}$ & $\mathrm{P}$ & $\eta^{2}$ & Absent & Present & Absent & Present & df & $\mathrm{F}$ & $\mathrm{P}$ & $\overline{\eta^{2}}$ \\
\hline \multirow{3}{*}{ Mean Score } & 2016 & 1 & 3.491 & .062 & .312 & 55.6 & 56.8 & 56.2 & 56.2 & 1 & .012 & .912 & .53 \\
\hline & 2017 & 1 & 8.469 & .004 & .391 & 60.3 & 59.4 & 60.3 & 59.4 & 1 & 1.995 & .158 & .46 \\
\hline & 2018 & 1 & .852 & .356 & .421 & 61.2 & 61.2 & 61.3 & 61.3 & 1 & .564 & .453 & .47 \\
\hline
\end{tabular}




\begin{tabular}{|c|c|c|c|c|c|c|c|c|c|c|c|c|c|}
\hline \multirow{3}{*}{ Science } & 2016 & 1 & 3.821 & .051 & .531 & 48.7 & 50.3 & 50.1 & 48.8 & 1 & 2.605 & .107 & .52 \\
\hline & 2017 & 1 & 8.160 & .004 & .382 & 55.0 & 53.0 & 55.0 & 53.0 & 1 & 6.303 & .012 & .50 \\
\hline & 2018 & 1 & .096 & .756 & .424 & 57.3 & 57.3 & 57.6 & 57.6 & 1 & .202 & .653 & .51 \\
\hline \multirow{3}{*}{ Math } & 2016 & 1 & 3.340 & .068 & .531 & 53.3 & 54.8 & 53.9 & 54.9 & 1 & .146 & .702 & .52 \\
\hline & 2017 & 1 & 3.704 & .054 & .395 & 60.6 & 60.1 & 60.6 & 60.1 & 1 & .446 & .504 & .53 \\
\hline & 2018 & 1 & .042 & .838 & .428 & 61.4 & 61.4 & 61.1 & 61.1 & 1 & .918 & .338 & .46 \\
\hline \multirow{3}{*}{ Urdu } & 2016 & 1 & 4.449 & .035 & .522 & 58.2 & 59.6 & 59.0 & 58.8 & 1 & .068 & .795 & .47 \\
\hline & 2017 & 1 & 9.753 & .002 & .398 & 60.5 & 60.3 & 60.5 & 60.3 & 1 & .084 & .773 & .51 \\
\hline & 2018 & 1 & 4.816 & .028 & .537 & 61.1 & 61.1 & 61.8 & 61.8 & 1 & .047 & .829 & .38 \\
\hline \multirow{3}{*}{ English } & 2016 & 1 & .560 & .454 & .462 & 50.6 & 51.2 & 50.1 & 51.7 & 1 & 4.611 & .032 & .42 \\
\hline & 2017 & 1 & .619 & .432 & .472 & 54.4 & 55.4 & 54.4 & 55.4 & 1 & 1.749 & .186 & .53 \\
\hline & 2018 & 1 & 1.765 & .184 & 521 & 57.7 & 57.7 & 58.0 & 58.0 & 1 & .389 & .533 & .38 \\
\hline \multicolumn{14}{|c|}{ Basic Facilities 2} \\
\hline \multirow{2}{*}{ DV } & \multicolumn{7}{|c|}{ Toilet } & \multicolumn{6}{|c|}{ Sewerage } \\
\hline & & $\mathrm{df}$ & $\mathrm{F}$ & $\mathrm{P}$ & $\eta^{2}$ & Absent & Present & $\mathrm{df}$ & $\mathrm{F}$ & $\mathrm{P}$ & $\eta^{2}$ & Absent & Present \\
\hline \multirow{3}{*}{ Mean Score } & 2016 & 1 & 4.778 & .029 & .53 & 55.5 & 56.9 & 1 & 6.930 & .008 & .53 & 57.0 & 55.4 \\
\hline & 2017 & 1 & .200 & .655 & .39 & 59.7 & 60.0 & 1 & 1.198 & .274 & .46 & 59.5 & 60.2 \\
\hline & 2018 & 1 & .124 & .725 & .42 & 61.4 & 61.4 & 1 & .482 & .487 & .53 & 61.7 & 61.7 \\
\hline \multirow{3}{*}{ Science } & 2016 & 1 & 12.29 & .000 & .52 & 48.0 & 50.9 & 1 & 8.680 & .003 & .39 & 50.7 & 48.3 \\
\hline & 2017 & 1 & .904 & .342 & .39 & 53.6 & 54.3 & 1 & .863 & .353 & .39 & 53.6 & 54.3 \\
\hline & 2018 & 1 & .280 & .597 & .53 & 57.7 & 57.7 & 1 & 3.568 & .059 & .42 & 57.9 & 57.9 \\
\hline \multirow{3}{*}{ Math } & 2016 & 1 & 4.048 & .044 & .46 & 53.3 & 54.8 & 1 & 6.314 & .012 & .52 & 55.0 & 53.1 \\
\hline & 2017 & 1 & .068 & .795 & .53 & 60.3 & 60.5 & 1 & .935 & .334 & .39 & 60.0 & 60.7 \\
\hline & 2018 & 1 & .399 & .528 & .39 & 61.1 & 61.1 & 1 & .037 & .848 & .47 & 61.5 & 61.5 \\
\hline \multirow{3}{*}{ Urdu } & 2016 & 1 & 4.333 & .037 & .39 & 58.2 & 59.6 & 1 & 7.472 & .006 & .51 & 59.8 & 58.0 \\
\hline & 2017 & 1 & .243 & .622 & .42 & 60.2 & 60.6 & 1 & 1.026 & .311 & .38 & 60.1 & 60.7 \\
\hline & 2018 & 1 & .785 & .376 & .52 & 61.5 & 61.5 & 1 & .004 & .952 & .42 & 61.8 & 61.8 \\
\hline \multirow{3}{*}{ English } & 2016 & 1 & .986 & .000 & .39 & 50.9 & 50.9 & 1 & .836 & .361 & .53 & 51.2 & 50.6 \\
\hline & 2017 & 1 & .261 & .167 & .43 & 54.4 & 55.4 & 1 & 1.277 & .258 & .38 & 54.5 & 55.4 \\
\hline & 2018 & 1 & 1.139 & .286 & .39 & 57.6 & 57.6 & 1 & .555 & .456 & .47 & 58.1 & 58.1 \\
\hline
\end{tabular}

Note: effect size $=\eta 2$ or partial $\eta 2$.

\section{Discussion, Conclusion, and implications}

In the recent decade, student examination scores are being used to measure education quality and economical instrument (Hanushek \& Woßmann, 2010; Aslam, 2003). It is an exclusive educational indicator that can quantifiably convey inputs' nature (Glewwe \& Jacoby, 1994). Likewise, standard examination records are extremely preferred by educational policy-makers for the formulation, evaluation, and implementation of policies (Aslam, 2003; Hamza, 2016; Hussain, 2018; Government of Punjab, 2020). Thus, in our longitudinal study, we were curious about the disposition of the most significant and vital inputs, which are most delicate and crucial in developing countries (Chudga et al., 2015) since previous studies stated that in low-income countries, the student learning outcome is highly dependent of the accessibility of necessary facilities like sanitation, electricity, along with distribution and corresponding school condition. For that reason, studies have claimed that developing countries' necessary facilities became the leading indicators of SES in boosting school performance (Murillo \& Roman, 2011). Further, previous studies criticized the inconsistent findings, methodological limitations, and less investigation (Durán-Narucki, 2008: Picus et al., 2009; Tayyaba, 2012; Nisar et al., 2017).

Hence, this study intended to fill those gaps through an evidence-based longitudinal study at Punjab province in Pakistan as a model due to its availability of large scale data throughout the years. Still, according to the fulfilled data census's contestability, we have comprised only the 2016,17,18 data census that embraces necessary data regarding school-level statistics, which qualified the study to tackle its purpose. Thus, the study's finding demonstrates that the province has shown a great revival in facilitating rural and urban schools with adequate facilities within the period due to collaboration between government and non-profit organizations (Aslam et al., 
2019: Government of Punjab, 2020). Year after year, the province built thousands of schools not for the symbol but with adequate facilities, plus the most fascinating is that this whole reform was that all parts of the province had a fair distribution of resources. Correspondingly, the study's finding demonstrates that after the long-term in these three-year interval ranges, Punjab province's primary educational national examination scores have shown ultra-progression each year. However, the progression of schools in Punjab in 2017 was considerably notable than any of the year score unwittingly, including subject-wise score. About the subject score, the finding illustrates that Punjab's primary school STEM score on the examination demonstrates a radical improvement throughout the year. Likewise, English scores enhanced in these last years (Rahim, 2017), in which a previous study criticized Punjab for low English scores (Hussain, 2018). Nevertheless, improvement does not mean achievement, since Punjab has exhibited a radical examination result improvement over the year, but it is far from achievement (Government of Punjab, 2020). For that reason, there should be a systematic and committed assess the effectiveness of available school facilities that costs the country a fortune (Hanushek, 1997).

Further, according to the study's purpose, we have investigated the distribution of necessary facilities among urban and rural schools and its influence on school performance. Thus, finding coincides with prior studies that rural schools trail their urban peers (Chudga, 2015; Rahim, 2017; OECD, 2019), and it is due to the small size school, and student learning behavior at rural schools made them outperform their urban counterparts (Sunday and Olatunde, 2011). Moreover, our findings demonstrate that Punjab province is virtually on the stage of zero sanitation infrastructure and basic facility difference between urban and rural, which previously arise rural schools fall behind the urban school in terms of facility and learning outcome (Murillo and Roman, 2011; OECD, 2019). Punjab government conduct a national examination for primary, middle and secondary school every year to evaluate the education system (Aslam, 2003; Hamza, 2016; Hussain, 2018; Government of Punjab, 2020). Paradoxically, the finding in line with the previous study in Punjab that rural school outperforms their urban counterparts in STEM subjects and Urdu language as long as the adequate resource is absolute (Tayyaba, 2012), although English score did not show a significant difference across the country, exhibit promising progress from previous studies (Hussain, 2018). Previous studies argued that besides school facilities' availability, their year-to-year structural condition significantly impacts the student learning process and their well-being (Durán-Narucki, 2008; Jasper et al., 2012; Maphoso \& Mahlo, 2014; UNICEF, 2018). Therefore, the study sheds light on the effect of classroom construction status on school performance. The finding indicated that in the academic year of 2016 and 2017 Punjab province, the school building condition has a significant effect on student academic achievement. However, in the 2018 academic year majority of primary schools renovate their school building to restore a smooth learning environment that results in zero effect of building condition that dispute previous studies (Chan, 1996; Earthman \& Lemasters, 1996; O'Neill \& Oates, 2001; Earthman, 2004; Durán-Narucki, 2008; Aslam et al., 2019), which was already denounced and proven by a longitudinal study that status of the school building has nothing to do with student performance (Picus et al., 2009).

The presence of toilet and drinking water in the school often claimed to be the essential school resource that predicts children's physical health and learning motivation (Durán-Narucki, 2008; Maphoso \& Mahlo, 2014; Jasper et al., 2012). Thus, the study's finding mentioned that the school's primary resources presence loses its robust effect on student examination scores throughout the year, which agrees with previous claims (Glewwe et al., 1994; Chudga et al., 2015; Adukia, 2016). These findings reflect how far Punjab province strived to assure adequate facilities across schools to change the perception of the inadequate school facility and developing country as two faces of the coin (Glewwe, 2002; Durán-Narucki, 2008; Jasper et al., 2012; Maphoso \& Mahlo, 2014; UNDESA, 2014; UNICEF, 2018). The study has shown two significant points; first, as long as there is an apparent facility discrepancy between schools, it will keep exhibiting influence on student learning output. Other provinces of Pakistan are experiencing a significant educational threat (Hamza, 2016; Hussain, 2018). So, earlier studies took Punjab as a model (Rahim, 2017; Tayyaba, 2012); second, this study spotlight on zero effect of necessary facilities on school performance as long as the government ascertains facilities in every school to make the teaching-learning process effective and to keep the children psychological and physical health (Chan \& Petrie, 1998; Maphoso \& Mahlo, 2014; Jasper et al., 2012). So our implication from this finding is that future scholars need to go after SES and student characteristics as (Tayyaba, 2012; Nisar et al., 2017), which are thought wrong since necessary facilities in Punjab are going to become out of the equation soon (Glewwe et al., 1994; Murillo \& Roman, 2011). Despite our evidence-based finding contradicts a recent national-level study in Pakistan claimed zero effect size of SES (Tayyaba, 2012; Rahim, 2017; Aslam, 2019). Moreover, the study showed evidence through the three years' data census that schools perform well in English subjects that are the medium of instruction. Still, the government is on the way to changing into Urdu (Government of Punjab, 2020), which is has a threat of taking this progress back to the time (Hussain, 2018). According to the recent Punjab government education 2020-2035 plan, the paramount general aim is to achieve SDG 4 (Government of Punjab, 
2020). As long as necessary steps and actions take into account, Pakistan's renaissance may not be far.

\section{Acknowledgement}

We would like to thank government of Punjab province of Pakistan for permitting us to access the data census to use it for the sake of this article aim. Further, we would like to show our gratitude for Faculty of Education of Southwest University in China in supervising and guiding our paper to reach this level.

\section{Funding}

The research was conducted without any financial aid or funding agency support.

\section{References}

Adukia, A. (2017). Sanitation and Education. American Economic Journal: Applied Economics, 9(2), 23-59. https://doi.org/10.1257/app.20150083

Aslam, M. (2003). The Determinants of Student Achievement in Government and Private Schools in Pakistan. The Pakistan Development Review, 42(4) Part II, 841-876.

Aslam, M., Malik, R., Rawal, S., Rose, P., \& Vignoles, A. (2019). Do government schools improve learning for poor students? Evidence from rural Pakistan. Oxford Review of Education, 45(6), 802-824. https://doi.org/10.1080/03054985.2019.1637726

Chan, T. C., \& Petrie, G. (1998). The brain learns better in well-designed school environments-the Association of Supervision and Curriculum Development. Classroom Leadership Online, 2(3), 1.

Chudgar, A., Chandra, M., \& Iyengar, R. et al. (2015). School resources and student achievement: Data from rural India. Prospects, 45, 515-531. https://doi.org/10.1007/s11125-015-9360-3

Durán-Narucki, V. (2008). School building condition, school attendance, and academic achievement in New York City public schools: A mediation model. Journal of Environmental Psychology, 28, 278-286. https://doi.org/10.1016/J.JENVP.2008.02.008

Earthman, G. I. \& Lemasters, L. (1996). Review of Research on the Relationship between School Buildings, Student Achievement, and Student Behavior. [S.1.]: Distributed by ERIC Clearinghouse. https://eric.ed.gov/?id=ED416666

Glewwe, P. (2002). Schools and skills in developing countries: Education policies and socioeconomic outcomes. Journal of Economic Literature, 40, 436-482. https://doi.org/10.1257/002205102320161258

Glewwe, P., \& Jacoby, H. (1994) Student Achievement and Schooling Choice in Low-Income Countries: Evidence from Ghana. The Journal of Human Resources, 29(3), 843-864. https://doi.org/10.2307/146255

Government of Punjab (2020). Punjab Education Sector Plan (2020-2025). Punjab, Pakistan.

Hanushek, E. A. (1997). Assessing the Effects of School Resources on Student Performance: An Update. Educational Evaluation and Policy Analysis, 19(2), 141-164. https://doi.org/10.3102/01623737019002141

Hanushek, E. A., \& Woßmann, L. (2010). Education and Economic Growth. International. Encyclopedia of Education, 2, 245-252.

Hussain, S. (2018) An Analysis of Government Primary Schools' Characteristics Influencing Student Achievement in Northern Sindh. Bulletin of Education and Research, 40(1), 89-98.

Jasper, C., Le, T.-T., \& Bartram, J. (2012). Water and Sanitation in Schools: A Systematic Review of the Health and Educational Outcomes. International Journal of Environmental Research and Public Health, 9(8), 2772-2787. MDPI AG. https://doi.org/10.3390/ijerph9082772

Maphoso, L. S. T., \& Mahlo, D. (2014). Basic Facilities and Academic Achievement: A Comparative Study between Boarding and Non-Boarding Schools. International Journal of Educational Sciences, 6(2), 309-315. https://doi.org/10.1080/09751122.2014.11890142

Murillo, F. J., \& Roman, M. (2011). School infrastructure and resources do matter the analysis of school resources' incidence on Latin American students' performance. School Effectiveness and School Improvement, 22(1), 29-50. https://doi.org/10.1080/09243453.2010.543538

Murillo, F. J., \& Román, M. (2011). School infrastructure and resources do matter: Analysis of the incidence of school resources on the performance of Latin American students. School Effectiveness and School Improvement: An International Journal of Research, Policy, and Practice, 22(1), 29-50. https://doi.org/10.1080/09243453.2010.543538 
Nisar, N., Mahmood, K. M., \& Dogar, H. A. (2017). Determinants of Students' Academic Achievement at Secondary School Level. Bulletin of Education and Research, 39(1), 145-158.

O'Neill, D. J. (2000). The Impact of School Facilities on Student Achievement, Behavior, Attendance, and Teacher Turnover Rate at Selected Texas Middle Schools in Region XIII ESC. Doctoral Dissertation. Texas: Texas A and M University, College Station.

Organization for Economic Co-operation and Development (OECD). (2019). Learning in Rural Schools: Insights from PISA, TALIS, and the literature. OECD Education Working Paper No. 196, OECD Publishing, Paris, France.

Picus, L. O., Marion, S. F., Calvo, N., \& Glenn, W. J. (2005). Understanding the Relationship Between Student Achievement and the Quality of Educational Facilities: Evidence from Wyoming. Peabody Journal of Education, 80(3), 71-95. https://doi.org/10.1207/s15327930pje8003_5

Rahim, B. (2017). Improving Primary Education in Pakistan: An Examination of the Association between School Autonomy and Children's Learning Outcomes. FIRE: Forum for International Research in Education, 4(1). https://doi.org/10.18275/ fire201704011129

Sunday, O., \& Olatunde, Y. (2011). School Location and Academic Achievement of Secondary School in Ekiti State, Nigeria. Asian Social Science, 7(5). https://doi.org/10.5539/ass. v7n5p170

Tayyaba, S. (2012). Rural-urban gaps in academic achievement, schooling conditions, student, and teachers' characteristics in Pakistan. International Journal of Educational Management, 26(1), 6-26. https://doi.org/10.1108/09513541211194356

Uline, C., \& Moran, M. (2008). The walls speak the interplay of quality facilities, school climate, and student $\begin{array}{llll}\text { achievement. Journal of Educational Administration, } & \text { 46(1), }\end{array}$ https://doi.org/10.1108/09578230810849817

UNDESA. (2014). Electricity and education: The benefits, barriers, and recommendations for achieving the electrification of primary and secondary schools. New York, USA.

UNESCO. (2017). Accountability in education: Meeting our commitments. Paris, France.

United Nations Children's Fund (UNICEF) and the World Health Organization. (2018). Drinking water, sanitation, and hygiene in schools: Global baseline report. New York, USA.

\section{Copyrights}

Copyright for this article is retained by the author(s), with first publication rights granted to the journal.

This is an open-access article distributed under the terms and conditions of the Creative Commons Attribution license (http://creativecommons.org/licenses/by/4.0/). 